E-Jurnal Ekonomi dan Bisnis Universitas Udayana 8.5 (2019): 465-474

\title{
DETERMINAN PENGAMBILAN KEPUTUSAN RUMAHTANGGA DALAM MENYEKOLAHKAN DAN MEMPERKERJAKAN ANAK : STUDI KASUS DI KABUPATEN SUMEDANG
}

\author{
Bayu Kharisma \\ Departemen Ilmu Ekonomi, Fakultas Ekonomi dan Bisnis, Universitas Padjadjaran \\ Jl. Dipati Ukur No. 35 Bandung, 40132, Indonesia \\ Email : bayu.kharisma@unpad.ac.id
}

\begin{abstract}
ABSTRAK
Tujuan penelitian ini adalah menggali dan mengidentifikasi aspek-aspek sosial ekonomi penduduk yang mempengaruhi pengambilan keputusan pendidikan melalui kegiatan penelitian yang selaras dengan masalah pendidikan dan tenaga kerja anak, di Kelurahan Cibeusi, Kecamatan Jatinangor, Kabupaten Sumedang. Metode yang dilaksanakan dalam penelitian ini adalah melalui pendampingan, workshop, sosialisasi, komunikasi partisipatif dan kegiatan lainnya. Bidang kegiatan program atau tema kegiatan penelitian ini yaitu pendidikan dan penyuluhan yang berkaitan dengan pendidikan anak, kegiatan edukatif dan pekerja anak. Berdasarkan hasil penelitian menunjukkan bahwa aspek sosial ekonomi keluarga yang berpengaruh terhadap pengambilan keputusan pendidikan, khususnya di Kelurahan Cibeusi, Kecamatan Jatinangor, Kabupaten Sumedang adalah pendapatan. Pendapatan merupakan faktor paling penting dalam menentukan keputusan rumahtangga dalam menyekolahkan anaknya. Faktor lainnya yang berpengaruh terhadap pengambilan keputusan pendidikan anak yaitu latar belakang pendidikan orang tua. Umumnya tingkat pendidikan di daerah Desa Cibeusi rata-rata adalah berpendidikan SD sampai SMP. Temuan ini mengindikasikan bahwa tingkat pendidikan orangtua sangat mempengaruhi tingkat partisipasi sekolah anak dan juga keinginan anak untuk sekolah. Dalam kondisi semacam ini diperlukannya orangtua yang berperan aktif dalam pengajaran gaya belajar seperti apakah yang cocok untuk siswa agar anak mau sekolah dan juga hasil belajar siswa meningkat.
\end{abstract}

Kata Kunci : pengambilan keputusan pendidikan, tenaga kerja anak, pendapatan, pendidikan orang tua

\section{ABSTRACT}

The purpose of this study is to explore and identify the socio-economic aspects of the population that influence educational decision making through service activities that are in harmony with the problems of education and child labor, in Cibeusi Village, Jatinangor District, Sumedang Regency. The method implemented in this service is through assistance, workshops, socialization, participatory communication and other activities. The field of program activities or the theme of this service activity is education and counseling relating to children's education, educational activities and child labor. Based on the results of service shows that the socio-economic aspects of the family that influence education decision making, especially in the Cibeusi Village, Jatinangor Sub-District, Sumedang Regency are income. Revenue is the most important factor in determining household decisions in sending their children to school. Other factors that influence children's educational decision making are the parents' educational background. Generally the level of education in the Cibeusi Village area is on average elementary to junior high school education. This finding indicates that the level of parental education greatly influences the level of children's school participation and also the child's desire for school. In such conditions, parents need to play an active role in teaching learning styles such as what is suitable for students so that children want to go to school and also student learning outcomes increase.

Keywords: education decision making, child labor, income, parental education 


\section{PENDAHULUAN}

Anak merupakan bagian terpenting dalam kehidupan sosial karena memiliki peran dan fungsi di keluarga serta lingkungan masyarakat. Mereka bagian dari sekumpulan individu yang memiliki interaksi sosial dan hidup bersama di masyarakat (Moeslichatoen, 1999). Hak anak dalam keluarga yaitu hak mendapatkan perhatian, kasih sayang, perlindungan, pertolongan dan pendidikan mendasar. Pendidikan mendasar dalam keluarga untuk membentuk karakter dan tumbuh kembang anak sebagaimana manusia seutuhnya. Demikian juga hak anak untuk mendapatkan akses pendidikan formal di sekolah. Selain mendapatkan hak, anak ada juga memiliki kewajiban dalam keluarga yaitu membantu, melindungi dan menolong orang tua. Anak yang dimaksudkan dalam hal ini adalah seseorang berusia dibawah 18 tahun yang termasuk pada anggota dalam keluarga. Indikator usia anak tersebut menunjukkan bahwa masa untuk anak dapat membentuk karakter dan menempuh pendidikan formal di sekolah karena anak berperan sangat penting sebagai generasi penerus.

Hak pendidikan anak melalui pendidikan sekolah dasar sebagaimana program pemerintah wajib belajar 12 tahun untuk mengatasi masalah kemiskinan, kemelaratan dan kebodohan. Mengatasi permasalahan sosial tersebut maka setiap anak wajib untuk menempuh pendidikan, minimal pendidikan dasar dapat diselesaikannya. Pendidikan merupakan hal yang penting dan sangat dibutuhkan oleh anak, demi kelangsungan hidup lebih baik dan mencapai cita-citanya. Mewujudkan hal tersebut maka dibutuhkan peran orang tua, pemerintah dan masyarakat.

Anak memiliki hak dan kewajiban serta tanggung jawab dalam keluarga dan di masyarakat. Keikutsertaan anak dalam kehidupan sosial menjadi bagian yang tidak terpisahkan dalam kehidupannya serta melekatnya hak dan kewajiban. Hak anak sejalan dengan kewajiban yang harus dilakukan. Anak memiliki kewajiban untuk bertanggung jawab atas hidup masa depannya dan keluarga, wajib membantu serta mengabdi pada orang tua. Terwujudnya hak dan kewajiban tersebut dibutuhkan kerjasama yang baik antara anak dan orang tua dalam keluarga. Kewajiban dan hak anak dalam proses pertumbuhan anak sampai dewasa tidak terlepas dari peran orang tua.

Proses perkembangan anak membutuhkan pendidikan dan kesehatan berkualitas untuk pertumbuhan fisik psikis yang sehat. Kualitas pendidikan dan kesehatan dapat terpenuhi sesuai dengan kondisi sosial ekonomi keluarganya. Kondisi ekonomi keluarga merupakan penentu untuk mencapai kualitas hidup anak. Jika kondisi ekonomi keluarga miskin merupakan 


\section{E-Jurnal Ekonomi dan Bisnis Universitas Udayana 8.5 (2019): 465-474}

masalah bagi anak-anak sebab terbatasnya segala kebutuhan anak dapat terpenuhi. Kondisi sosial keluarga dimana kesadaran membentuk keluarga harmonis maka memberikan dampak positif bagi perkembangan anak. Dengan demikian kondisi sosial ekonomi keluarga termasuk menentukan masuknya anak menjadi pekerja anak, dimana kondisi sosial ekonomi keluarga tidak harmonis dan terbatas dalam mencukupi kebutuhannya sehingga melibatkan anak dalam kegiatan ekonomi.

Konsep yang akan digunakan untuk mengatasi permasalahan yang ada yaitu mengadakan sosialisasi, pendampingan dan konsultasi tentang pendidikan untuk anak sangatlah penting dan mencegah terjadinya pekerja anak dengan menciptakan cara belajar yang menarik sehingga daya tarik anak dalam belajar menjadi meningkat. Dengan demikian, tujuan penelitian ini adalah menggali dan mengidentifikasi aspek-aspek sosial ekonomi penduduk yang mempengaruhi pengambilan keputusan pendidikan melalui kegiatan penelitian yang selaras dengan masalah pendidikan dan tenaga kerja anak, khususnya di Kelurahan Cibeusi, Kecamatan Jatinangor, Kabupaten Sumedang.

\section{GAMBARAN UMUM MASYARAKAT KABUPATEN SUMEDANG}

Lokasi pelaksanaan penelitian di Desa Cibeusi, Kabupaten Sumedang dilaksanakan pada tanggal 8 Oktober 2018 - 31 Desember 2018. Desa Cibeusi merupakan sebuah desa yang berada di wilayah Kecamatan Jatinangor. Lokasinya berada di bagian barat wilayah kecamatan dan berbatasan langsung dengan Kabupaten Bandung di Kecamatan Cileunyi. Jika dilihat dari pusat Kecamatan Jatinangor, posisinya berada di sebelah barat dengan jarak sekitar tiga kilometer. Desa Cibeusi pada awalnya merupakan bagian dari wilayah Desa Cipacing. Ketika Kecamatan Cimanggung dimekarkan menjadi dua kecamatan yaitu Kecamatan Cimanggung dan Kecamatan Cikeruh (sebelum kemudian berganti nama menjadi Kecamatan Jatinangor pada tahun 2000), Desa Cipacing termasuk wilayah yang beralih menjadi bagian dari wilayah Kecamatan Cikeruh bersama lima wilayah Desa lainnya. Setelah pemekaran wilayah kecamatan ini, setiap desa yang berada di wilayah Kecamatan Cikeruh dimekarkan menjadi dua wilayah termasuk juga Desa Cipacing. Desa Cipacing dimekarkan wilayahnya menjadi dua wilayah yaitu Desa Cipacing dan Desa Cibeusi. Desa Cibeusi mengambil wilayah di bagian utara sementara Desa Cipacing di bagian selatan.

Secara geografis, Desa Cibeusi dikelilingi oleh wilayah-wilayah sebagai berikut: Desa Sindangsari Kecamatan Sukasari dan Desa Cileles di sebelah utara, Desa Cileles dan Desa Sayang di sebelah timurnya, Desa Cipacing di sebelah selatan serta Kabupaten Bandung di sebelah baratnya. Sementara secara administratif, Desa Cibeusi terdiri atas tiga dusun yaitu 
Dusun Cibeusi, Dusun Bojongeureun dan Dusun Sadang. Untuk jumlah Rukun Warga dan Rukun Tetangganya masing-masing sebanyak 14 RW dan 39 RT.

Desa Cibeusi memiliki luas wilayah sebesar 164 hektar. Luas wilayah tersebut terbagi ke dalam beberapa peruntukan yaitu sebagai lahan pertanian, lahan pemukiman dan lahan lainnya. Dalam hal ini, yang dipergunakan sebagai lahan pertanian sebesar 50 persen dari luas totalnya atau sekitar 82 hektar. Lahan pertaniannya terbagi ke dalam dua jenis yaitu lahan pesawahan dan lahan non-pesawahan. Luas lahan pesawahannya sebesar 34 persen dari luas total atau sekitar 55,76 hektar. Lahan pertanian bukan pesawahan atau termasuk lahan ladang, huma dan perkebunan seluas 16 persen atau sekitar 26,24 hektar. Sebesar 15 persennya atau sekitar 24,6 hektar dipergunakan sebagai lahan pemukiman dan pekarangan. Seluas 15 persen sisanya atau 24,6 hektar dipergunakan untuk keperluan lainnya seperti lahan fasilitas umum. Masih berdasarkan sumber data yang sama, pada tahun 2013 Desa Cibeusi memiliki jumlah penduduk sebanyak 10.809 jiwa. Dengan rincian sebanyak 5.569 orang berjenis kelamin laki-laki ditambah 5.240 orang berjenis kelamin perempuan. Jumlah kepala keluarganya sebanyak 1.771 KK. Kepadatan penduduk Desa Cibeusi sebesar 5.874 orang untuk tiap kilometer luas wilayahnya.

Profil dan kondisi sosial ekonomi masyarakat sasaran yang akan dilibatkan dalam kegiatan penelitian ini umumnya memiliki pendapatan menengah ke bawah. Adapun kelompok sasaran utama yaitu orang tua. Pada dasarnya keputusan orang tua rumahtangga terhadap investasi pendidikan dapat dilakukan dalam 2 (dua) hal. Pertama, ketika orang tua dihadapkan pada guncangan pendapatan maka orang tua akan mendorong anaknya untuk terlibat langsung pada aktivitas atau kegiatan yang dapat menghasilkan pendapatan bagi keluarga dengan memperkerjakan anaknya sehingga waktu yang dialokasikan untuk pendidikan akan berkurang. Kedua, adanya guncangan pendapatan berdampak pada rendahnya tingkat partisipasi sekolah, baik bersifat permanen maupun sementara. Pada situasi ini orang tua akan memutuskan untuk memberhentikan anaknya sekolah. Sementara itu, kelompok sasaran lainnya adalah anak- anak tingkat pendidikan dasar dan menengah serta pekerja anak atau anak bekerja.

\section{METODE PENELITIAN}

Metode yang dilaksanakan dalam penelitian ini adalah melalui pendampingan, workshop, sosialisasi, komunikasi partisipatif dan kegiatan lainnya. Bidang kegiatan program atau tema kegiatan penelitian ini yaitu pendidikan dan penyuluhan yang berkaitan dengan pendidikan 


\section{E-Jurnal Ekonomi dan Bisnis Universitas Udayana 8.5 (2019): 465-474}

anak, kegiatan edukatif dan pekerja anak. Berbagai program yang akan dilaksanakan di Desa Cibeusi antara lain:

1. Penyuluhan tentang pentingnya pendidikan anak usia dini dalam era modern ini. Dalam penyuluhan ini juga dilakukan diskusi bersama warga untuk bersama membangun program lanjutan agar Desa Cibeusi ini mempunyai program mingguan yang dikhususkan untuk anak-anak.

2. Bantuan secara sukarela untuk mengajarkan anak-anak dan menanamkan perilaku gemar membaca buku. Hal ini dimaksudkan sebagai ajang pelatihan dini sebelum anak-anak menginjak pendidikan lanjutan,sehingga ke depannya masyarakat mampu membangun fasilitas taman bacaan atau kegiatan edukatif lain ini secara mandiri. Selain itu, dengan melibatkan masyarakat dalam kegiatan ini, diharapkan rasa peduli terhadap anak timbul sehingga program ini dapat berkelanjutan.

3. Melakukan kegiatan mengajar yang dilakukan oleh peserta penelitian. Hal ini dimaksudkan untuk menambah pengetahuan anak-anak mengenai beragam hal yang sudah dipelajari dari masing-masing peserta.

4. Melakukan kegiatan pembekalan terhadap orang tua sebagai guru pribadi anak. Dalam penbekalan tersebut terdapat ilmu terapan yang dapat diterapkan dengan mudah. Hal ini memungkinkan setiap ibu rumah tangga memiliki kepiawaian sikap dalam memotivasi anak untuk belajar dan menuntaskan pendidikan. Kesadaran keluarga untuk menyelenggarakan pendidikan terbaik bagi anaknya merupakan modal utama memutus mata rantai pekerja anak.

Kegiatan penelitian ini ditujukan agar masyarakat mengetahui pentingnya pendidikan anak usia sekolah dasar hingga menengah. Dengan demikian, pada akhir kegiatan ini, diharapkan masyarakat sudah memiliki taman bacaan dan membuat pendidikan luar sekolah. Selain itu, untuk kegiatan luar sekolah, masyarakat sudah memiliki program setiap minggunya yang dikhususkan untuk anak-anak agar program yang sudah dilaksanakan oleh peserta penelitian dan dosen dapat optimal. Diharapkan program ini mampu meningkatkan kesadaran masyarakat akan pentingnya pendidikan dalam pengambilan keputusan menyekolahkan anak atau mempekerjakan anak. Mahasiwa dan dosen akan merekap data ini untuk kemudian dievaluasi peningkatan manfaat yang terjadi. Hasil evaluasi dapat digunakan untuk perbaikan pelaksanaan kegiatan penelitian tahun berikutnya karena untuk beberapa tahun ke depan, Desa Cibeusi masih akan menjadi lokasi sasaran program penelitian.

\section{PEMBAHASAN}


Bayu Kharisma. Determinan Pengambilan Keputusan Rumah Tangga Dalam Menyekolahkan...

Penelitian terhadap masyarakat ini diikuti oleh 45 peserta perwakilan dari orang tua, sekolah dan anak. Pelaksanaan dimulai pada pukul 07.00-14.00 WIB. Kegiatan dilaksanakan di SD Cipacing 1 dan Ruang Rapat Kantor Desa Kelurahan Cibeusi, Kecamatan Jatinangor, Kabupaten Sumedang.

\section{Monitoring dan Evaluasi Program}

1) Tahap awal, dilakukan sebelum kegiatan penelitian dilaksanakan, terutama pada waktu persiapan sampai pada kegiatan program telah dilakukan.

- Memastikan perancangan rencana kegiatan penelitian berjalan sesuai target yang telah ditetapkan.

- Memastikan terlaksanakannya kegiatan penelitian.

2) Tahap proses, dilakukan pada waktu kegiatan penelitian sedang berlangsung.

- Mengendalikan keserasian pelaksanaan penelitian dengan perencanaan yang telah ditetapkan.

- Memastikan program penelitian berjalan dengan lancar.

- Memastikan terjadinya hubungan timbal balik antara peserta penelitian dan masyarakat.

- Mengendalikan proses penelitian agar berlangsung secara efektif dan mencapai hasil yang sesuai dengan rencana.

3) Tahap akhir, dilakukan pada waktu kegiatan penelitian akan dan telah berakhir.

- Memastikan semua faktor dalam pelaksanaan kegiatan ini mendapatkan hubungan timbal balik yang bermanfaat.

- Memastikan tercapainya tujuan yang telah ditentukan.

\section{Hal yang Dilakukan Pada Saat Monitoring dan Evaluasi :}

1. Memberikan informasi yang valid tentang perkembangan program penelitian yang sudah dilaksanakan.

2. Memberikan informasi mengenai keadaan atau kondisi desa sebelum dan sesudah dilaksanakan program penelitian.

3. Memberikan informasi mengenai kajian untuk menyelesaikan masalah dan kekurangan yang dialami dilapangan.

4. Memberikan informasi mengenai kekurangan dan kelebihan program penelitian tersebut.

5. Memberikan umpan balik terhadap program penelitian yang sedang berjalan

6. Menjadikan pembelajaran terhadap metode pelaksanaan program penelitian 


\section{E-Jurnal Ekonomi dan Bisnis Universitas Udayana 8.5 (2019): 465-474}

Berbagai pembahasan yang akan dilakukan di Kelurahan Cibeusi, Kecamatan Jatinangor, Kabupaten Sumedang antara lain:

1. Penyuluhan dan sosialisasi tentang pentingnya pendidikan anak dalam keluarga. Dalam penyuluhan ini juga dilakukan diskusi bersama warga, aparat desa dan pihak sekolah.

2. Menanamkan perilaku gemar membaca buku. Hal ini dimaksudkan sebagai ajang pelatihan dini sebelum anak-anak menginjak pendidikan lanjutan,sehingga ke depannya masyarakat mampu membangun fasilitas taman bacaan atau kegiatan edukatif lain ini secara mandiri. Selain itu, dengan melibatkan masyarakat dalam kegiatan ini, diharapkan rasa peduli terhadap anak timbul sehingga program ini dapat berkelanjutan.

3. Bantuan secara sukarela untuk mengajarkan anak-anak. Hal ini dimaksudkan untuk menambah pengetahuan anak-anak mengenai beragam hal yang sudah dipelajari dari masing-masing anak dan memberikan beberapa permainan seperti memegang anggota tubuh yang diintruksikan dilakukan hanya untuk murid laki-laki, estafet karet dilakukan hanya untuk murid perempuan, cerdas cermat, tebak binatang, dan ular naga. Permainan ular naga dilakukan di lapangan SD Cipacing 1. Semua murid yang terlibat diberi hadiah berupa snack ringan dan beberapa permen.

4. Melakukan kegiatan pembekalan terhadap orang tua sebagai guru pribadi anak. Dalam penbekalan tersebut terdapat ilmu terapan yang dapat diterapkan dengan mudah. Hal ini memungkinkan setiap ibu rumah tangga memiliki kepiawaian sikap dalam memotivasi anak untuk belajar dan menuntaskan pendidikan. Kesadaran keluarga untuk menyelenggarakan pendidikan terbaik bagi anaknya merupakan modal utama memutus mata rantai pekerja anak.

5. Memberikan penyuluhan mengenai pentingnya mendidik anak sejak dini dan juga memberikan informasi terhadap warga mengenai beasiswa pendidikan. Selain itu, berdiskusi permasalahan apa saja yang terjadi di lingkungan desa cibeusi. Menurut keterangan Pak Yanto selaku ketua RT pendidikan di desa Cibeusi sudah merata namun masih ada sebagian kecil yang tidak bisa bersekolah karena masalah biaya dan juga umumnya masyarakat memiliki pendapatan yang relatih rendah.

6. Berdasarkan hasil diskusi menunjukkan bahwa aspek sosial ekonomi keluarga yang berpengaruh terhadap pengambilan keputusan pendidikan, khususnya di Kelurahan Cibeusi, Kecamatan Jatinangor, Kabupaten Sumedang adalah pendapatan. Pendapatan merupakan faktor paling penting dalam menentukan keputusan rumahtangga dalam menyekolahkan anaknya. Hasil temuan ini konsisten dengan penelitian yang dilakukan sebelumya bahwa 
pada saat pendapatan meningkat maka partisipasi sekolah anak-anak di desa meningkat dan pekerja anak perempuan menurun, namun pada saat pendapatan rumahtangga mengalami penurunan akibat semakin tingginya biaya hidup maka partisipasi sekolah anak-anak akan menurun dan pekerja anak akan muncul. Temuan ini konsisten dengan studi sebelumnya bahwa pada saat terjadi guncangan, rumahtangga berusaha mengurangi pengeluaran pendidikan anaknya, khususnya anak perempuan dalam melakukan consumption smoothing (Cameron \& Worswick, 2001). Hal tersebut secara tidak langsung berimplikasi pada tingginya pekerja anak perempuan dibandingkan dengan anak laki-laki. Hasil temuan ini sejalan studi lainnya bahwa rumahtangga umumnya memprioritaskan pendidikan anak lakilaki dibandingkan perempuan pada kondisi atau situasi sulit (Dreze \& Sen, 2011).

7. Faktor lainnya yang berpengaruh terhadap pengambilan keputusan pendidikan anak yaitu latar belakang pendidikan orang tua. Umumnya tingkat pendidikan di daerah Desa Cibeusi rata-rata adalah berpendidikan SD sampai SMP. Temuan ini mengindikasikan bahwa tingkat pendidikan orangtua sangat mempengaruhi tingkat partisipasi sekolah anak dan juga keinginan anak untuk sekolah. Dalam kondisi semacam ini diperlukannya orangtua yang berperan aktif dalam pengajaran gaya belajar seperti apakah yang cocok untuk siswa agar anak mau sekolah dan juga hasil belajar siswa meningkat. Orangtua yang mempunyai pendidikan tinggi umumnya akan mengarahkan anak untuk belajar sesuai dengan gaya belajar siswa yang sesuai dengan karakteristik anak dan berusaha untuk mendukung pendidikan anak sampai ke jenjang lebih tinggi.

\section{KESIMPULAN}

Program penelitian dengan tema "Determinan Pengambilan Keputusan Rumahtangga dalam Menyekolahkan dan Memperkerjakan Anak" ini dirasa sangat penting, mengingat tema tersebut sangat berkaitan dengan upaya peningkatan tingkat partisipasi pendidikan anak. Pendidikan dalam keluarga atau rumahtangga tidak mempunyai suasana seperti pendidikan di sekolah. Peran pendidikan dalam keluarga tidak akan menemukan ruangan yang dipenuhi fasilitas seperti bangku dan meja, papan tulis, dan media pembelajaran lainnya. Selain itu, tidak akan menemukan pendidik yang mengenakan uniform tertentu yang biasa dipanggil dengan sebutan 'guru'. Pendidikan dalam keluarga memiliki ciri khas tersendiri. Hal ini dimungkinkan karena pendidikan dalam keluarga bukanlah pendidikan yang 'diorganisasikan' melainkan pendidikan yang 'organik', yang didasarkan pada spontanitas, intuisi, pembiasaan dan improvisasi. Meskipun demikian, dalam pendidikan keluarga maka akan menemukan orang 


\section{E-Jurnal Ekonomi dan Bisnis Universitas Udayana 8.5 (2019): 465-474}

tua yang fungsinya tidak jauh berbeda dengan guru di sekolah atau dosen di perguruan tinggi yaitu mentransfer pengetahuan.

Dalam konteks pendidikan dalam keluarga, orang tua bertugas mentransfer pengetahuan tetapi bukan pengetahuan tentang mata pelajaran tertentu, melainkan pengetahuan tentang kehidupan. Dengan kata lain, pendidikan dalam keluarga merupakan segala usaha yang dilakukan oleh orang tua dengan pembiasaan dan improvisasi untuk membantu perkembangan pribadi anggota keluarga yang disebut anak.

Aspek sosial ekonomi keluarga atau rumahtangga yang berpengaruh terhadap pengambilan keputusan pendidikan, khususnya di Kelurahan Cibeusi, Kecamatan Jatinangor, Kabupaten Sumedang adalah pendapatan. Pendapatan merupakan faktor paling penting dalam menentukan keputusan rumahtangga dalam menyekolahkan anaknya. Selain itu, faktor lainnya yang berpengaruh terhadap pengambilan keputusan pendidikan anak yaitu latar belakang pendidikan orang tua.

\section{DAFTAR PUSTAKA}

Cameron, L \& Worswick, L (2001). "Education Expenditure Responses to Crop Loss in Indonesia: A Gender Bias. University of Chicago.

Depdiknas. 2002. Kurikulum dan Hasil Belajar Pendidikan Anak Usia Dini. Jakarta: Pusat Kurikulum, Balitbang Bepdiknas.

Dreze, J \& Sen, A. 2011. "Hunger and Public Action. WIDER Studies in Development Economics". Oxford: Oxford University Press

Fitrianti, R \& Habibullah. (2012). "Ketidaksetaraan Gender Dalam Pendidikan; Studi Pada Perempuan di Kecamatan Majalaya Kabupaten Karawang”. Sosiokonsepsia Vol. 17, No. 012012

King, E.M. (1986). "Narrowing The Education Gender GAP In Developing Countries". Policy Brief. Rand Corp

King, E.M. (2009). "The Global Economic Crisis, Education, and Development Partnerships". Keynote Presentation at the HDN-WBI Course on Innovations in Partnerships, September 21, 2009, Washington DC.http://info.worldbank.org/etools/docs/library/252243/Keynote presentation,Elizabeth King.pdf(diakses pada tanggal 1 April 2013)

Moeslichatoen. R. 1999. Metode Pengajaran di Taman Kanak-Kanak. Jakarta: PT. Rineka Cipta Sanders, 
Bayu Kharisma. Determinan Pengambilan Keputusan Rumah Tangga Dalam Menyekolahkan...

Patmonodewo, S 1995. Buku Ajar Pendidikan Prasekolah. Jakarta: Depdiknas. Dirjen Dikti. Proyek Pendidikan Tenaga Akademik.

Simatauw, M et al (2001). "Gender dan Pengelolaan Sumberdaya Alam”. Yogyakarta. Yayasan PIKUL.

Steve. 1999. Strukture of Preschool Education. Available to htttp//www.percental.org.

Suryadi, A., \& Idris, E. (2004). "Kesetaraan Gender dalam Bidang Pendidikan”. Bandung: PT. Ganesindo.

Undang-undang Republik Indonesia Tentang Sistem Pendidikan Nasional Nomor 20 Tahun 2003. 